\title{
NEW DATA ON THE ORIENTAL XANTHOLININI. 40. NEW SPECIES AND NEW RECORDS IN THE COLLECTION OF TATEO ITO, KYOTO (COLEOPTERA STAPHYLINIDAE)
}

\author{
$268^{\text {th }}$ Contribution to the knowledge of the Staphylinidae
}

\begin{abstract}
(*) Museo di Storia Naturale dell'Università di Firenze, sezione di Zoologia "La Specola", via Romana 17, 50125 Firenze, Italy; e-mail: arnaldo.bordoni@fastwebnet.it

Bordoni A. - New data on the Oriental Xantholinini. 40. New species and new records in the collection of Tateo Ito, Kyoto (Coleoptera Staphylinidae). $268^{\text {th }}$ Contribution to the knowledge of the Staphylinidae

Achmonia formosa sp. n. (Taiwan) and Emathidis itoi sp. n. (Vietnam) are described and figured. The following species are new records for the cited regions: Pachycorynus hoabinensis Bordoni, 2002 (Laos), Achmonia laosiana Bordoni, 2016 (Vietnam), Indolinus mitomorphoides (Coiffait, 1984) (Meghalaya), Indolinus laosianus Bordoni, 2013 (Vietnam), Phacophallus japonicus (Cameron, 1933) (Myanmar), Hypnogyra sichuanica Bordoni, 2003 (Laos) and Atopolinus nahanganus Bordoni 2004 (Laos).
\end{abstract} Emathidis.

Key Words: Coleoptera, Staphylinidae, Xantholinini, Oriental Region, new species, new records, Achmonia,

\section{INTRODUCTION}

In the Xantholinini sent to me in study by Tateo Ito (Kyoto), I found a lot of specimens from some countries of the Oriental Region (Meghalaya, Myanmar, Malaysia, Laos and Vietnam). These pages are the result of the study of this material.

I add also some species from Taiwan. This island, normally included in the Indochinese sub-region, constitutes a land of contact between neighboring faunule, belonging to the Palaearctic and Oriental zoogeographical regions, with a significant presence of endemisms for the insularity and the presence of high mountains that became areas of refuge for those genera that have a predominantly northern distribution in the Oriental Region, such as Atopolinus Coiffait, 1982.

Depositories: cB: coll. Bordoni, Firenze, Italy; cI: coll. Ito, Kyoto, Japan

\section{TAXONOMY}

\section{Pachycorynus hoabinensis Bordoni, 2002}

Material eXAmined - Laos, Piarhat, W Vientian $50 \mathrm{~km}$, Vientian Prov., Y. Katayama 22.IV.2007, 1 ô (cI).

Note - This species was described from Vietnam (Hoa Binh). New record for Laos. This is the first record since the description of the species.

\section{Thyreocephalus perakensis Bordoni, 2004}

Material eXAmined - Malaysia, W Perak, $25 \mathrm{~km} \mathrm{NE}$ Ipoh, 1200 m, Banjaran Titi Wangsa mts., Korbu Mt., P. Pacholátko 11-16.I.1999, 1 (cI).

NotE - This species was described from the same locality here cited. First record since the description of the species.
Thyreocephalus laticeps (Erichson, 1839)

Material eXAmined - E Malaysia, Sabah, Trus Madi Mt, 1200 m, M. Sawai 8-20.IV.2001, 1 \& (cI).

Distribution - This species is known from Myanmar, Malacca Peninsula, Sumatra, Mentawei, Java and Borneo (BORDONI, 2002).

\section{Achmonia formosa sp. n.}

Material eXAmined - Holotype $\widehat{\jmath}$ : NE Laos, Mt Phu Pane, Hua Phan Prov., 1200-1600 m, St. Jakl et at. 1022.V.2011 (cI); paratypes: same data, 2 ○ (cI), 1 ऽ (cB).

DESCRIPTION - Length of body $17 \mathrm{~mm}$; from anterior margin of head to posterior margin of elytra: $10 \mathrm{~mm}$. Body shiny; head and pronotum black, elytra red with brown dark scutellum, abdomen brown black, antennae and legs reddish brown. Head and pronotum and related puncturation as in Fig. I, 1. Labrum as in Fig. I, 2, with very prominent median protrusions. Elytra sub-quadrangular, as long and wide as pronotum, with sub-rectilinear sides and marked humeral angles. Surface with some series of fine punctures, among which stands out a median, oblique series; scutellum with some fine punctures. Abdomen with numerous, evident punctures, arranged in 4-5 series on each segment.

Tergite and sternite of the male genital segment as in Fig. I, 3-4. Aedeagus (Fig. I, 5) very large, $4.8 \mathrm{~mm}$ long, sub-rectangular, with short and broad median lobe; parameres very short and robust; inner sac tape-like, folded on itself one-two times, covered with fine scales.

ETYMology - The specific epithet refers to the Latin formosus- $a$ - um (formosus) in relation to the shape of the aedeagus.

DistRIBUTION - The species is known only from the type locality. 


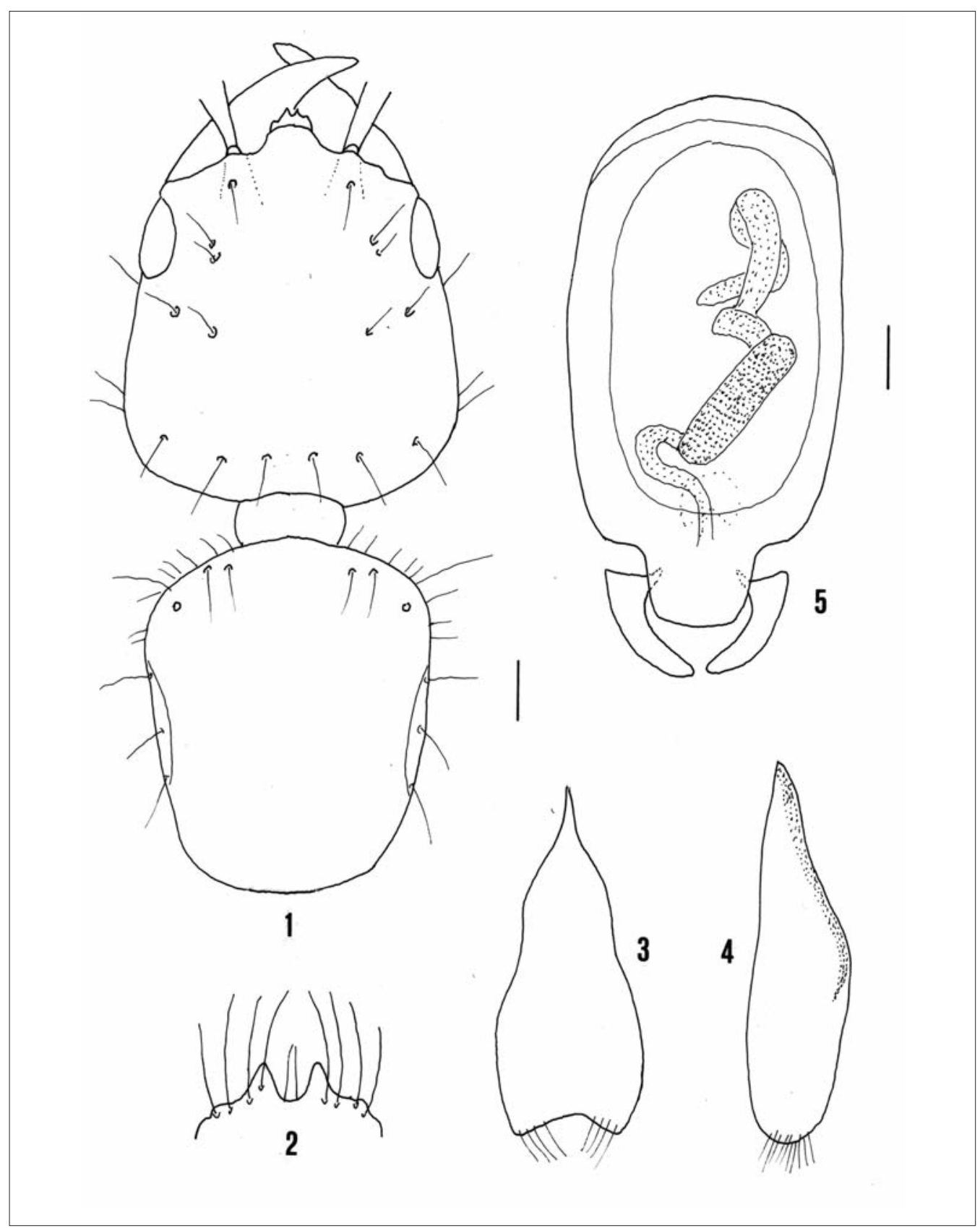

Fig. I - 1. Head and pronotum (scale bar: $0.5 \mathrm{~mm}$ ); 2. labrum, 3-4. tergite and sternite of the male genital segment, 5. aedeagus (scale bar: $0.5 \mathrm{~mm}$ ) of .Achmonia formosa sp. $\mathrm{n}$.

NotE - The aedeagus of this species is very big, probably the biggest that I known in Xantholinini. Achmonia formosa differs from A. laosiana Bordoni, 2016 from Laos by shape of head-pronotum, puncturation, size, colouration and especially by the very large aedeagus with short median lobe and parameres.

\section{Achmonia shibatai Bordoni, 2010}

MATERIAL EXAMINED - Taiwan, Aowanda, Nantou Hsien, $1050 \mathrm{~m}$, T. Ito 18.V.2013, $1 \widehat{\jmath}(\mathrm{cI}), 1$ \& (cB).

Note - This species seems endemic of Taiwan. This is the first record since the description of the species.
Achmonia laosiana Bordoni, 2016

Material eXAmined - Vietnam Lam Dong Prov., BidoupNui Ba Nat. Park, Giang Ly., 1500 m, K. Harusawa 13.IV.2014, 1 q (cI); Ha Giang Distr., Ma le, 1200 m, T. Ito 3.V.2011, 1 ठै (cI)

Note - This species was described from numerous localities of NE Laos. New record for Vietnam. This is the first record since the description of the species.

Indolinus mitomorphoides (Coiffait, 1984)

Material eXAmined - NE India, Meghalaya, Tura, M. Tryzna \& P. Benda V-VI.2002, 1 ○ (cI). 
DISTRIBUTION - This species is known from Myanmar, North India, Nepal, Thailand and Laos (BORDONI, 2002). New record for Meghalaya.

Indolinus laosianus Bordoni, 2013

MATERIAl EXAMINED - Vietnam, Khu Oulich, Tay Thien, T. Ito 29.IV.2008, 1 ふ (cI).

Note. Apart from the species described from Taiwan (I. formosae Bordoni, 2002) and Hong Kong (I. sculptilis Bordoni, 2002), the genus appeared represented especially by the most common and widespread $I$. mitomorphoides. Recent collections in Laos, Thailand and Vietnam have allowed to add other taxa of particular interest (I. vietnamicus Bordoni, 2012 and I. laosianus) which considerably extend the range of distribution of the genus.
New record for Vietnam. This is the first record since the description of the species. I re-propose the figure of aedeagus (Fig. II, 1) to better highlight the structure of the inner sac.

Phacophallus japonicus (Cameron, 1933)

Material eXAMINEd - Myanmar, Shwe Hninsi, Mayangone, Yangon, Y. Kusakabe IV-V.2006, 4 exx. (cI), 1 ex. (cB); Vietnam, Gia Nghia, Dak Nong Prov., 500 m, Y. Kusai 27.III.2013, 1 ex. (cI); Vietnam, Khu Oulich, Ty Thienm, T. Ito 29.IV.2008, 1 ex. (cI); Laos, $70 \mathrm{~km} \mathrm{NE}$ Vientiane, Ban Phabat, $150 \mathrm{~m}, 18^{\circ} 16.1 \mathrm{~N}, 103^{\circ} 10.9 \mathrm{E}, \mathrm{E}$. Jendek \& O. Sausa 27.IV-1.V.1997, 3 exx. (cI), 1 ex. (cB); Laos, Kammouan, Nakai route n. 8, 560 m, E. Jendek \& O. Sausa 4-8.V.1998, 1 ex. (cI); N Laos, 20 km NW Louang Namtha, $21^{\circ} 09.2 \mathrm{~N}, 101^{\circ} 18.7 \mathrm{E}, 900 \pm 100 \mathrm{~m}$, E. Jendek \& O. Sausa 5-11.V.1997, 1 ex. (cI).

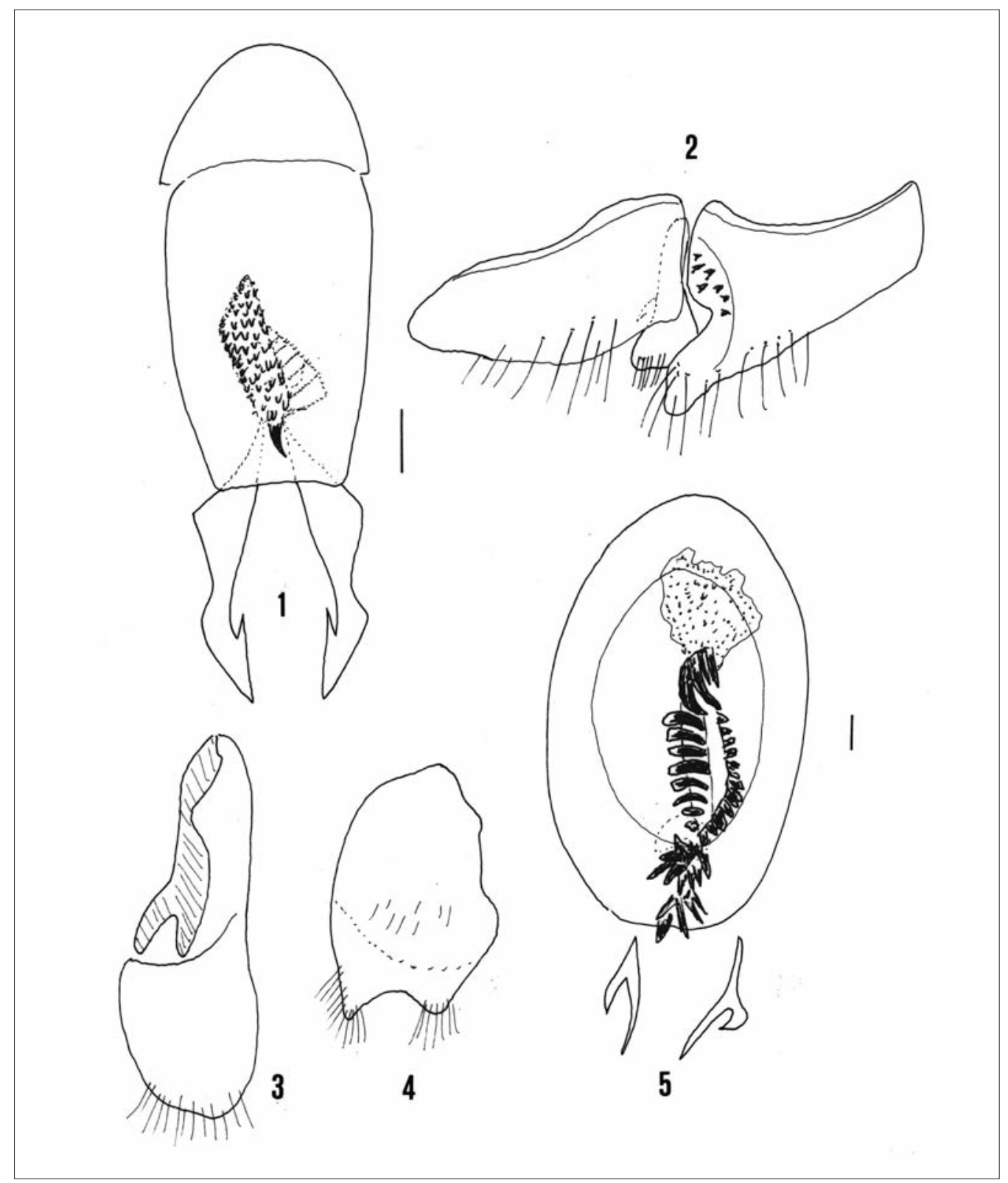

Fig II - 1. Aedeagus of Indolinus laosianus Bordoni; 2. male genital segment, 3-4. tergite and sternite of the male genital segment, 10. aedeagus (scale bar: $0.1 \mathrm{~mm}$ ) of Emathidis itoi $\mathrm{sp} . \mathrm{n}$. 
DistriBUTION - This species is known from Thailand to South China, Sumatra, Java, Bali and already cited from Vietnam and Laos (Bordoni, 2002). New record for Myanmar.

\section{Phacophallus flavipennis (Kraatz, 1859)}

Material examined - Taiwan, Puli, Nantou Hsien, T. Muraki 18.V.2013, 1 ex. (cI).

Distribution - The species is known from Sri Lanka, India, Nepal, Myanmar, Malay Peninsula, Philippines, Vietnam, Borneo and from several localities in Taiwan (BORDONI, 2002, 2011).

\section{Erymus eumorphus Bordoni, 2002}

Material eXamined - Malaysia, W Perak, $25 \mathrm{~km}$ NE Ipoh, 1200 m, Banjaran Titi, Wangsa mts, Korbu Mt, P. Pacholátko 27.I-2.II.1999, 1 đ (cI), 1 ○ (cB).

NOTE - I refer the specimens to this species, despite some differences in the aedeagus. The species was described from Borneo (Kalimantan Barat). New record for Malaysia. This is the first record since the description of the species.

Megalinus metallicus (Fauvel, 1895)

Material eXAmined - Vietnam, Sapa Distr., Ca Cat Park, Y. Kusui 4.V.2009, 1 ठै (cI).

DistriBution - This species, quite variable in size and structures of inner sac of the aedeagus, occurs in the montains from Pakistan to Taiwan (BORDONI, 2002).

\section{Hypnogyra sichuanica Bordoni, 2003}

Material eXAmined - N Laos, Oudom Xai Prov., Nam Minag riv., 39 km SE Miang Xai, 1200 m, Lao V.1999, 1 ठ઼ (cl).

Note - This species was described (Bordoni, 2003 a) from South Shaanxi (Qinliang Shan, Zhouzhi-Foping pass, $105 \mathrm{~km} \mathrm{SW} \mathrm{Xi'an)} \mathrm{and} \mathrm{for} \mathrm{mistake} \mathrm{described} \mathrm{as} \mathrm{if} \mathrm{it} \mathrm{was}$ collected in Sichuan !. New record for Laos. This is the first record since the description of the species.

\section{Emathidis itoi sp. n.}

MATERIAL EXAMINED - Holotype $\widehat{\jmath}$ : Vietnam, Ha Giang Distr., Pho Bang, 1500 m, T. Ito 2.V.2011 (cI).

DESCRIPTION - Length of body $6.1 \mathrm{~mm}$; from anterior margin of head to posterior margin of elytra: $3 \mathrm{~mm}$. Body shiny, reddish amaranth; antennae and legs testaceous. Head ovoid, a little dilated posteriad, with rounded posterior angles. Eyes small and very little protruding. Surface of head with fine, spaced puncturation on the sides. Pronotum ovoidal, longer and slightly narrower than head, with very oblique anterior margins, obsolescent anterior angles, and not sinuate sides. Surface with dorsal series of 7-8 superficial punctures and lateral series of 4 punctures. Elytra short, sub-rectangular, much more short and narrow than pronotum, with sub-parallel sides and obsolete humeral angles. Surface with fine, very spaced puncturation, arranged in 4 series on each elytra. Abdomen with traces of more or less polygonal micro-reticulation and fine puncturation, arranged in 2 series on each segment.

Male genital segment as in Fig. II, 2; tergite of the same (Fig. II, 3) with thickened left margin (probably teratology); sternite of the same as in Fig. II, 4. Aedeagus (Fig. II, 5) 2 mm long, ovoid, with small, slender, asymmetrical pseudoparameres; inner sac with 2 series of different scales.

ETYMology - Patronymic. The species is dedicated to the friend and colleague Tateo Ito (Kyoto).

DisTRIBUTION - The species is known only from the type locality.

Note - This uncommon genus was represented untill now only by two species [E. delucida (Bordoni, 2002) from Vietnam (Bao Loc) and E. humerosa (Bernhauer, 1934) from Sichuan (Hwa-yin Shan and Nitou Tatsienlu)] (BORDONI, 2002; 2003). Emathidis itoi differs from these species especially by the structure of the male genital segment and by the inner sac of the aedeagus.

\section{Atopolinus nahanganus Bordoni, 2004}

Material eXAmined - N Laos, Oudom Xai Prov., Nam Miang riv., 30 km SE Miang Xai, 1200 m, Lao V.1999, 2 ठ (cI), 1 đै (cB).

Note - This species was described from Vietnam: Na Hang Res. (BordONI, 2004a). New record for Laos. This is the first record since the description of the species.

Atopolinus shibatai Bordoni, 2002

Material EXAMINED - Taiwan, Aowanda, Nantou Hsien,

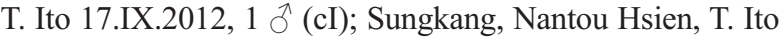
16.IX.2012, 1 ठ (cB).

DisTRIBUTION - This endemic species occurs in Nantou, Hualien and Chiai Hsien (BordonI, 2002; 2011)

\section{Atopolinus subtiliphallus Bordoni, 2011}

Material EXAmined - Taiwan, Sungkang, Nantou Hsien, T. Ito 16.IX.2012, 1 ऊ (cI).

DisTRIBUTION - This species was known until now only from the type locality. This is the first record since the description of the species.

\section{ACKNOWLEDGEMENTS}

I wish to thank warmly my colleague Tateo Ito for providing the material to this study.

\section{REFERENCES}

Bernhauer M., 1934 - Siebenter Beitrag zur Staphylinidenfauna Chinas - Entomologische Nachrichtenblatt, 8, 1: 1-20. 
BORDONI A., 2002 - Xantholinini della Regione Orientale (Coleoptera: Staphylinidae). Classificazione, filogenesi e revisione tassonomica - Memorie del Museo regionale di Scienze naturali, Torino 33: $998 \mathrm{pp}$.

Bordoni A., 2003 - Contributo alla conoscenza degli Xantholinini della Cina. II. (Coleoptera, Staphylinidae) Fragmenta entomologica, 34, 2: 255-292.

Bordoni A., 2003a - Contributo alla conoscenza degli Xantholinini della Cina. IV. Un nuovo genere e nuove specie raccolti da Michael Schülke nello Shaanxi e nel Sichuan (Coleoptera, Staphylinidae) - Beiträge zur Entomologie, 53, 2: 253-275.

Bordoni A., 2004 - Nuovi dati per la conoscenza degli Xantholinini della Regione Orientale. V. Daolus hromadkai gen. n., sp. n. del Nepal e Thyreocephalus perakensis $s p . n$. della Malesia (Coleoptera, Staphylinidae) Entomologica, Bari, 38: 83-89.

Bordoni A., 2004a - Nuovi dati per la conoscenza degli Xantholinini della Regione Orientale. VI. Specie del Vietnam (Coleoptera, Staphylinidae) - Fragmenta entomologica, 36, 2: 129-136.

BORDONI A., 2010 - Description of the first Thyreocephalus and Daolus from Taiwan (Coleoptera, Staphylinidae) Annalen des Naturhistorischen Museums, Wien, B, 111: 55-59.

BORDONI A., 2011 - New data and records on Xantholinini of Taiwan collected by Ales Smetana, with description of new species (Coleoptera, Staphylinidae) - Redia, 94: 2533.

Bordoni A., 2012 - New data on the Oriental Xantholinini. 28. New species and new records from Vietnam
(Coleoptera, Staphylinidae) - Fragmenta entomologica, 44, 1: 79-86.

Bordoni A., 2013 - New data on the Xantholinini from the Oriental Region. 32. New species and new records of North Laos in the collection Hayashi (Coleoptera, Staphylinidae) - Japanese Journal of Systematic Entomology, 19, 2: 191-198.

Bordoni A., 2016 - New data on the Xantholinini of the Oriental Region. 38. New species and new records for Laos from the collections of the Naturhistorisches Museum, Basel (Coleoptera, Staphylinidae) - Entomologica Basiliensia et Collectionis Frey, 35: 133-150.

CAMERon M., 1933 - New species of Staphylinidae (Col.) from Japan - The Entomologist's Montly Magazine, 69: 168-175.

Colffait H., 1982 - Staphylinidae (Col.) de la région himalayenne et de l'Inde. (I. Xantholininae, Staphylininae et Paederinae) - Entomologica Basiliensia, 7: 231-302.

CoIfFAIT H., 1984 - Contribution à la connaissance des Staphylinides de l'Himalaya (Coleoptera, Staphylinidae) - Annales de la Société entomologique de France (n. s.), 20, 4: 373-387.

ERICHSON W.F., 1839 - Genera et species Staphylinorum insectorum coleopterorum familiae. F. H. Morin, Berlin, $954 \mathrm{pp}$.

FAUVEL A., 1895 - Staphylinides nouveaux de l'Inde et de la Malaisie - Revue d'Entomologie: 180 -286.

KraAtz G., 1859 - Die Staphylinen-Fauna von Ostindien, insbesondere der Insel Ceylan - Archiv der Naturgeschichte, 25, 1: 1-193. 
24 - Blank Page 